\title{
Павлычева Е.Д.
}

Московский государственный областной университет

\section{ХАРАКТЕРИСТИКА ОСОБЕННОСТЕЙ ПОНЯТИЯ «РЕЧЕВОЙ ПОРТРЕТ»}

Аннотация. В статье представлен краткий обзорный анализ использования в современных фрилологических работах понятия «речевой портрет». Рассматриваются особенности данного понятия (его сущность, структура, содержание), определяется его специфика в контексте ретроспективного представления информационно-аналитического материала. Предлагается авторская разработка и представление (в табличной фрорме) результатов сравнительного анализа основных компонентов, входящих в понятие «речевой портрет»: языковой портрет, коммуникативный портрет, речевая характеристика, лингвокультурный типаж.

Ключевые слова: амплуа, имидж, коммуникативный портрет, лингвокультурный типаж, персонаж, речевая характеристика, речевое поведение, речевой портрет, роль, социопсихолингвистический портрет, стереотип, языковой портрет.

\section{E. Pavlycneva}

Moscow Region State University

\section{CHARACTERISTIC FEATURES OF THE CONCEPT OF "VERBAL PORTRAIT"}

Abstract. The article gives a brief analysis of the use of the concept of "verbal portrait" in modern philological works, discusses the characteristics of this concept (its nature, structure, content). Specific realization of the concept in the context of the retrospective presentation of informational and analytical material is studied. The results of the comparative analysis are presented in the form of a table where the main components included in the concept of "verbal portrait" - linguistic portrait, communicative portrait, speech characteristics, linguo-cultural type - are shown.

Key words: image, communicative portrait, lingal cultural type, character, verbal behavior, verbal portrait, role, socio-psycho-linguistic portrait, stereotype, linguistic portrait.

В современной филологической литературе понятие «речевой портрет» обладает высокой степенью практического использования. Но при этом необходимо заметить, что данное понятие вплоть до второй половины прошлого столетия (40-60-е гг.) чаще всего встречается в литературоведческих работах при описании приёмов и средств создания художественного образа персонажа. Но постепенно понятие «речевой портрет» становится актуальным и для языковедов. Более того, очевидно, под влиянием принципа антропоцентризма и идей антрополингвистики многоаспектное исследование данного понятия привело к пониманию того, что понятие «речевой портрет» является сложным по своей

(с) Павлычева Е.Д., 2015. 
структуре, в которой могут быть выделены новые - видовые - понятия, такие как «языковой портрет», «коммуникативный портрет», "речевая характеристика», «речевое поведение», «лингвокультурный типаж».

Как показал анализ современной научной литературы, общепринятым, чаще всего используемым определением понятия «речевой портрет» является следующее описание: речевой портрет - это «средство общения, передачи информации от человека к человеку, по сути дела, специфическая форма взаимодействия людей в процессах их деятельности, осуществляющаяся, главным образом, при помощи языка» [5, c. $10-16 ; 13$, с. $79-85 ; 21$, с. 5-9].

Согласно широко известному «Словарю-справочнику лингвистических терминов» Д.Э. Розенталя и М.А. Теленковой, речевая характеристика - это «подбор особых для каждого действующего лица литературного произведения слов и выражений как средство художественного изображения персонажей» [16, с. 364]. Нетрудно заметить, что лексикографы рассматривают данное понятие как литературоведческое.

Понятие «речевое поведение» связано с процессом выбора языка либо языкового варианта для построения социально корректного высказывания [10] и чаще всего рассматривается как предмет исследования социолингвистики.

Понятие «лингвокультурный типаж» связано с исследованием многообразных проявлений личности, с анализом их особенностей и попытками обобщения: роль (социальная, психологическая, литературная, культурологическая и т.д.); стереотип в контексте устоявшегося отношения к происходящим событиям, действиям, поступкам и т.д.; амплуа (реальное, виртуальное, прогностическое и т.д.); персонаж как действующее лицо и имидж с точки зрения искусственного образа, формируемого в общественном или индивидуальном сознании средствами массовой коммуникации и лингвопсихологического программирования (воздействия) и т.д. [9, c. $5-25 ; 14$, с. $125-141 ; 18]$.

На высокую степень актуальности понятия, обозначенного сочетанием слов «речевой портрет», указывает анализ современной лингвистической литературы: понятие «речевой портрет» используется многими учёными, в их числе А.В. Асадуллаева, О.Г. Алюнина, О.С. Ахманова, Л.Б. Бойко, И.В. Гуляева, И.В. Иванцева, О.С. Иссерс, А.Ю. Коровина, Л.П. Крысин, С.В. Попова, Т.В. Старцева, И.С. Шильникова, И.В. Щеглова, Е.А. Ярмахова и др. При этом необходимо отметить, что имеется разница в том, какой смысл вкладывает в используемое сочетание слов каждый исследователь.

Так, например, А.В. Асадуллаева использует то определение понятия «речевой портрет», которое создано Л.П. Крысиным: речевой портрет есть «представленная в определённой форме лингвистическая (языковая) манера, предназначенная для образования какого-либо образа (модели) языковой личности» [2; 12, с. 90-106].

В работах О.Г. Алюниной понятие «речевой портрет» рассматривается в тесной связи с особенностями и спецификой самой «языковой личности» или какого-либо конкретного «социального сообщества» в определённом устном и эпистолярном выговоре (речи) [1]. 
Необходимо указать на то, что О.Г. Алюнина в своих исследованиях уделяет внимание и речевому поведению как составному компоненту понятия «речевой портрет». По мнению автора, при описании речевого портрета необходимо выделять следующие характерные особенности: осуществление операций по составлению речевого портрета проходит с учётом множественности факторов, собранных при непосредственном прямом включённом или латентном наблюдении; основой для процедур составления речевых портретов предстаёт комбинаторный комплекс так называемых дискурсивных практик; речевой портрет, по сути своей природы, не представляет собой результат исследований лингвиста, так как он разрабатывается (программируется и моделируется) спонтанно. Однако сейчас мы наблюдаем множество примеров фальсификации таких портретов под воздействием массмедиа и компьютерных технологий [1].

В исследованиях Л.Б. Бойко, посвящённых разработке основ теории социально-групповых диалектов, устанавливается взаимосвязь образа (модели) речевого портрета и типажа [4].

И.В. Гуляева указывает на то, что понятия "речевой портрет» и «лингвокультурный типаж» представляют собой соотносимые явления, ибо описывают личность посредством её коммуникативного поведения. Но при этом исследовательница подчёркивает мысль о том, что названные понятия не являются синонимами [6].

Во многих работах термины «языковой портрет» и «речевой портрет» используются как синонимичные, близкие или даже вовсе совпадающие в своём значении. Но имеются и такие работы, в которых подчёркивается различие в значениях названных понятий. Так, для изучения проблем формирования методологических основ достаточно новой научной дисциплины - лингвоперсонологии; как считает Иванцева И.В., разведение понятий «языковой портрет» и «речевой портрет» необходимо и правомочно в силу их различия и несводимости одного к другому [7, с. 27-43].

В работах О.С. Иссерс при рассмотрении понятия «речевой портрет» внимание акцентируется на коммуникативном поведении личности («коммуникативный портрет»), поскольку она считает, что само понятие «коммуникативный портрет» связано с анализом характеристики речевого поведения личности [8, с. 63-75].

А.Ю. Коровина в работе, посвящённой анализу особенностей лингвокультурного типажа «английский сноб», осуществляет попытку отделения понятия «лингвокультурный типаж» от понятия «языковая личность». При этом следует отметить, что автор в данном исследовании не употребляет словосочетание "речевой портрет» и, следовательно, не рассматривает структуру данного понятия [11].

Понятие «лингвокультурный типаж» является предметом исследования в работах С.В. Поповой и Т.В. Старцевой, которые рассматривают его во взаимодействии с когнитивными конструктами, такими как стереотип и кониепт $[15 ; 17]$.

Подобное мнение относительно понятия «речевой портрет» высказывается и И.С. Шильниковой, которая определяет названное понятие как «... выбор одних элементов, характеризующих речевое поведение и упо- 
требление их в речи в зависимости от условий общения и неупотребление, осознанное или подсознательное отклонение других» [19].

В исследованиях И.В. Щегловой уделяется внимание таким понятиям, как «типаж», «концепт», «языковая личность», но не рассматривается понятие «речевой портрет» [20].

В работе Е.А. Ярмаховой понятия «коллективный речевой портрет» и «типаж» представлены как синонимичные. А искомое понятие - «речевой портрет» - анализируется как в личностном, так и в общественном значении его трактовки [22].

При анализе научной литературы нельзя обойти вниманием словарь лингвистических терминов О.С. Ахмановой. Анализ вокабуляра названного словаря показал, что лексикограф не проводит чёткого разделения понятий «речевой портрет» и «речевая характеристика». Объяснением этому может служить то, что данные явления обла- дают достаточно большой синонимической схожестью, и, возможно поэтому, толкование их смысла приводится только в привычном лингвистическом виде, оставляя «за бортом» целый спектр социокультурных и психофизиологических особенностей [3].

Одним из основных значимых результатов проведённого анализа современной лингвистической литературы является констатация того, что в большом числе публикаций понятия «коммуникативный портрет» и «речевой портрет» применяются как синонимичные [2; 6; 8; 12, с. 90-106; 19; 20]. Вторым значимым результатом является утверждение того, что чаще всего в исследованиях используется словосочетание "речевой портрет», которое вместе с термином «языковой портрет», считается обозначением определённого понятия.

Итоги проведённого анализа можно обобщить и представить в виде таблицы (см. табл. 1).

Таблица 1

\section{Результаты сравнительного анализа использования понятия «речевой портрет» ${ }^{1}$}

\begin{tabular}{|c|c|c|c|c|c|c|c|}
\hline \multirow{2}{*}{ 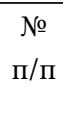 } & \multirow[t]{2}{*}{ Персоналии } & \multirow{2}{*}{$\begin{array}{c}\text { Работы } \\
\text { (порядковый номер в списке } \\
\text { использованной литературы) }\end{array}$} & \multirow[t]{2}{*}{ Год } & \multicolumn{4}{|c|}{ Основные понятия } \\
\hline & & & & ЯП, (РП) & КП & PX & ЛКТ \\
\hline 1 & Асадуллаева А.В. & {$[2]$} & 2011 & + & - & - & - \\
\hline 2 & Алюнина О.Г. & {$[1]$} & 2010 & + & - & - & - \\
\hline 3 & Ахманова О.С. & {$[3]$} & 2004 & + & - & + & - \\
\hline 4 & Бойко Л.Б. & {$[4]$} & 2009 & + & - & - & - \\
\hline 5 & Гуляева И.В. & {$[6]$} & 2009 & + & - & - & + \\
\hline 6 & Иванцева И.В. & {$[7]$} & 2008 & + & - & - & - \\
\hline 7 & Иссерс O.С. & {$[8]$} & 2000 & - & + & - & - \\
\hline 8 & Коровина А.Ю. & {$[11]$} & 2008 & - & - & - & + \\
\hline 9 & Крысин Л.П. & {$[12]$} & 2001 & + & - & - & - \\
\hline
\end{tabular}

Продолжение таблицы на с. 114

${ }^{1}$ Примечания к таблице: ЯП - языковый портрет, (РП) - (речевой портрет), КП коммуникативный портрет, $P X$ - речевая характеристика, ЛКТ - лингвокультурный типаж. 
Окончание таблицы 1

\begin{tabular}{|c|l|c|c|c|c|c|c|}
\hline \multirow{2}{*}{$\begin{array}{c}\text { № } \\
\text { п/п }\end{array}$} & \multicolumn{1}{|c|}{ Персоналии } & \multicolumn{2}{c|}{$\begin{array}{c}\text { Работы } \\
\text { (порядковый номер в списке }\end{array}$} & \multicolumn{3}{|c|}{ Основные понятия } \\
\cline { 5 - 7 } & & использованной литературы) & & ЯП, (РП) & КП & РХ & ЛКТ \\
\hline 10 & Попова С.В. & {$[15]$} & 2012 & - & - & - & + \\
\hline 11 & Старцева Т.В. & {$[17]$} & 2012 & - & - & - & + \\
\hline 12 & Шильникова И.С. & {$[19]$} & 2010 & + & - & - & - \\
\hline 13 & Щеглова И.В. & {$[20]$} & 2010 & + & - & - & - \\
\hline 14 & Ярмахова Е.А. & {$[22]$} & 2005 & + & - & - & + \\
\hline
\end{tabular}

В заключение следует отметить, что существуют значительные разночтения в понимании самого понятия, его структуры и сущности основных и производных дефиниций понятия «речевой портрет»; имеется насущная необходимость в систематизации наработанного информационно-аналитического материала; нужны комплексные исследования, способные ответить на большое количество проблемных вопросов, связанных с понятием «речевой портрет»; назрела необходимость в классификации видов данного понятия и приёмов выделения характерологических признаков для дальнейшей их типологизации.

В качестве рабочего определения понятия "речевой портрет» можно предложить следующее, основанное на обобщении имеющихся в литературе описаний: речевой портрет - это совокупность личностно-коммуникативных языковых черт индивида, представленная в виде открытой модели, отражающей также и коллективное описание представителя какой-либо конкретной культуры, обладающего способностью к проведению аналитических операций.

\section{ЛИТЕРАТУРА:}

1. Алюнина О.Г. Понятие речевого портрета в современных лингвистиче- ских исследованиях [Электронный pecypc]. URL: http://www.google.ru/ url? sa=t\&rct=j\&q=1 (дата обращения: 02.11.2015).

2. Асадуллаева А.В. Исторический криминальный лингвокультурный типаж «английский пират»: дис. ... канд. филол. наук. Волгоград, 2011. 170 с.

3. Ахманова О.С. Словарь лингвистических терминов. 2-е изд., стер. М.: УРСС: Едиториал УРСС, 2004. $571 \mathrm{c}$.

4. Бойко Л.Б. Основы теории социально-групповых диалектов: дис. ... докт. филол. наук. М., 2009. 379 с.

5. Гавра Д.П. Основы теории коммуникации. 1-е изд. СПб.: Питер, 2011. C. 10-16.

6. Гуляева Е.В. Лингвокультурный типаж «американский адвокат»: дис. ... канд. филол. наук. Волгоград, 2009. 176 с.

7. Иванцева И.В. Проблемы формирования методологических основ лингвоперсонологии // Вестник ТомГУ. Сер.: Филология. 2008. № 3 (4). С. 27-43.

8. Иссерс О.С. Коммуникативный портрет языковой личности (на примере писем Сергея Довлатова) // Русистика сегодня. 2000. № 1-4. С. 63-75.

9. Карасик В.И., Дмитриева О.А. Лингвокультурный типаж: к определению понятия // Аксиологическая лингвистика: лингвокультурные типажи: сб. науч. тр. / под ред. В.И. Карасика. Волгоград: Парадигма, 2005. С. 5-25.

10. Кожемякина В.А. и др. Словарь социолингвистических терминов. Кожемякина В.А., Колесник Н.Г., Крючкова Т.Б., 
Парфенова О.С., Трушкова Ю.В. при участии Биткеевой А.Н. и Горячевой М.А. / под ред. Михальченко В.Ю.; Российская академия наук. Институт языкознания / Российская академия лингвистических наук. Институт иностранных языков. М., 2006. 312 с.

11. Коровина А.Ю. Лингвокультурный типаж «английский сноб»: дис. ... канд. филол. наук. Волгоград, 2008. 226 с.

12. Крысин Л.П. Современный русский интеллигент: попытка речевого портрета // Русский язык в научном освещении. 2001. № 1. С. 90-106.

13. Макеева С.О. Речевой портрет в круге смежных понятий // Актуальные проблемы германистики, романистики и русистики: материалы и тезисы докладов ежегодной международной конференции, 7 февраля 2014 г., Екатеринбург / Урал. гос. пед. ун-т ; под ред. Н.Н. Сергеевой; науч. ред. Е.Е. Горшкова. Екатеринбург, 2014. Ч. 3. С. 79-85.

14. Ослон А. Уолтер Липпман о стереотипах: выписки из книги «Общественное мнение» // Социальная реальность. 2005. №4. C. 125-141.

15. Попова С.В. Лингвокультурный типаж «школьная учительница»: субъектное позиционирование: автореф. дис. ... канд. филол. наук. Волгоград, 2012. 21 с. 16. Розенталь Д.Э. и др. Словарь лингвистических терминов. [Электронный реcypc]. http://www.gumer.info/bibliotek Buks/Linguist/DicTermin/index.php (дата обращения: 02.11.2015).

17. Старцева Т.В. Когнитивное моделирование лингвокультурного типажа EMIGRANT: на материале ирландской литературы XX-XXI в.: автореф. дис. ... канд. филол. наук. Кемерово, 2012. 21 с. 18. Судаков К.В. Динамические стереотипы, или Информационные отпечатки действительности. М.: ПЕР СЭ, 2002. $128 \mathrm{c}$.

19. Шильникова И.С. Когнитивное моделирование лингвокультурного типажа The Man of Property (на материале цикла Д. Голсуорси): дис. ... канд. филол. наук. Иркутск, 2010. 245 с.

20. Щеглова И.В. Лингвокультурный типаж «чиновник» (на материале русского языка): дис. ... канд. филол. наук. Волгоград, 2010. 170 c.

21. Яковлев И.П. Ключи к общению. Основы теории коммуникаций. СПб.: Авалон, Азбука-классика, 2006. 240 с.

22. Ярмахова Е.А. Лингвокультурный типаж «английский чудак»: дис. ... канд. филол. наук. Волгоград, 2005. 191 с. 